\title{
A Misnomer European Travelers and Missionaries Portrayal of Islam and the Muslims of Ethiopia (16th to 19th Century)
}

\author{
Endris Ali Haider, endrishaider@gmail.com
}

Wollo University, College of Social Science and Humanities, Department of History and Heritage Management

\begin{abstract}
Ethiopians were described by travelers and missionaries from a large number of European countries at different times. Attracted by the great natural feature of the country or influenced by the writings and sayings of their own compatriots, many European travelers and missionaries had visited the country at different times and had left a descriptive work about the people, religion, social condition and various aspects of the Abyssinia. The very good nature of their existence in Ethiopia is that they have produced accounts on the various encounters of the country. Their accounts have been used by many researchers as firsthand information. The missionaries and travelers descriptive work, however, is characterized by some kinds of prejudices and stereotypes towards Islam and the Muslims of Ethiopia. In fact such prediction is expected when assessing the value of such kind of literatures. This is because they are not professional writers and hence their judgment inevitably could be influenced by either their own personal beliefs or any other factor. This article deals with the misnomer description of European travelers and missionaries towards Islam and the Muslims of Ethiopia from the sixteenth to the nineteenth centuries. Sources for this study were used by making a meticulous analysis of various travel accounts in corroboration with other secondary materials.
\end{abstract}

KEYWORDS: Europeans, Travelers, Missionaries, Muslims, description

\section{Islam and Its Contact with Ethiopia}

The first contact between Ethiopia and Islam goes back to the seventh century when the Prophet Muhammad ordered his companions to go to Ethiopia for fearing the persecution from the Quraish ruling oligarchy. Ethiopia was chosen by the prophet as "a land of righteousness" where he believed that God will protect his companions from persecution by his opponents. The coming of the first emigrants and the hospitality they received from the then king of Axum-al Nejashi had led to the expansion of Islamic culture and tradition to the future of Ethiopia ${ }^{11}$.

Ethiopia or Abyssinia is known by her neighboring Arab countries and people of Arab origin as habasha (meaning people of mixed race $)^{2}$. The usage of the term, "the land of habesha,"is also mentioned in the works of Arab Chroniclers and travelers like Ibn Hawqal, al-Masudi and Ibn Kaludin ${ }^{3}$. But the argument given by Michael Russel as to this appellation is "scornfully disclaimed" by the Abyssinians is totally unjustified. Abyssinia is a country of medley of regions where the Jews, Christians and the Muslims had been contributing their own share for the development of various cultures for

1 J. Spencer Trimingham, Islam in Ethiopia (London; Oxford University Press,1965),p.44;Haggai Erlich, Ethiopia and the Middle East (London: Lynne RiennerPublishers,1994),p.6; Sergew Hable Selassie, Ancient and Medieval Ethiopian History to1270 (Addis Ababa :United Printers n.d), p.191

2 Michael Russel,The History of Nubia and Abyssinia ( New York: J\&.J.Harper,1883),p.84 3 Erlich, p. 12 many centuries ${ }^{4}$. It is also a country of mixed race where there had been different ethnic groups, languages and cultures since time immemorial. But prejudiced and ignorant description of some Europeans to this kind of Ethiopia's cultural and religious amalgam is most often revealed in their literatures. According to Teshale, Ethiopia is unique in Africa in terms of the various types of religions i.e. the presence of an ancient form of Christianity, the existence of African "traditional religions" and a place where Islam gained its first ground 5 . The unique feature of the country as a source of the Nile River, the mountainous landscape as well as the ancient presence of Christianity must have also contributed to the growth of Europeans curiosity about Ethiopia ${ }^{6}$.

After crossing the Red Sea, the expansion of Islam to the horn of Africa was more facilitated by traders and ulamas (Muslim holy men).The arrival of these ulamas from Arabia which was mainly related to the growth of the Red Sea trade, had largely contributed to the spread of Islam to the people of the Horn of Africa ${ }^{7}$. The Muslim traders popularly known as

\footnotetext{
4 Russel,p.84

5 Teshale Tibebu, The Making of Modern Ethiopia,1898-1974 (Lawrenceville: The Red Sea press,1995), p.57

6 Deresse Ayenachew, "Environmental Descriptions of European Travelers in Ethiopia (16th to 19th c)", In Claimatic and Environmental Challenges :Learning from the Horn of Africa (Addis Ababa: Center Francaisdes etudes ethiopiennes, 2019), p.1

7 Mordechai Abir, Ethiopia and the Red Sea :the Rise and Decline of the Solomonic Dynasty and the Musslim European Rivalry in the Region (New York:Frank Class Company Limited, ), p.XVI
} 
jabartis had significantly played for the spread of Islam from the coastal areas to the interior regions of Ethiopia. By the time when it was hard for any foreign missionaries to preach and spread their religions in Abyssinia, every Muslim emigrant (traders) were serving as missioner and able to proselytize their religions ${ }^{8}$. According to Hussien Ahmed the activities of these Muslim traders, i.e. the preaching of their religion was said to have tolerated by the Christian government of Ethiopia. Though it was temporary, it had led to the establishment of small trading quarters which later on played as centers for the diffusion of Islam to other places ${ }^{9}$.

Though, Christianity was as a national religion and the Semitic speaking inhabitants who have been inhabiting stretching from the north to the central highlands predominates, Abyssinia had traditionally been diverse society consisting of non-Semitic pagan and Muslim elements of equal historical status $^{10}$. A Portuguese priest Jorome Lobo had described Abyssinia as an empire inhabited by Moors, Jews and Pagans where such a diversity of people and religion is the reason that the kingdom at different forms of government, and their laws and customs are tremendously various ${ }^{11}$. Despite the presence of such a medley of Ethiopians' culture, religions and ethnic diversity, the priest arrogantly put as "except the Damotes, and the Agaws which approach somewhat nearer to civility are entirely rude and barbarous." 12 This kind of description is preposterous and without evidence and inevitably shows his prejudiced attitude. The same kind of ridiculous description is made by Pereira to the hot low land inhabitants of the Afar peoples of Ethiopia as "a Mohammedan wild hordes addicted to plunder and cruelty."13 The literary element which is embodied in these writers work does not properly explain the nature of the peoples being explained and it is a clear indication of their personal or religious predicament. They overlooked the cultural and religious interplay of the various inhabitants of historical Abyssinia. Most of the sources and even the many important ones which will be part of the discussion pertinent to the issue under consideration are not free from these kinds of problems. European travelers and Missionaries who came to Ethiopia at different times motivated by various factors such as missionary zeal or colonialist interest or in the name of making scientific study, and some professional writers who have their concept of Islam tried to describe the religion and its followers in an extraordinary manner. The main intention of this paper is to make some analysis on this misnomer European description of Islam and the Muslims of Ethiopia in the periods from the sixteenth to the nineteenth centuries.

\section{Europeans Concept of Islam and the Muslims of Ethiopia}

8 C.F.REY, "Abyssinia and the Abyssinians of Today,"The Geographical Journal,Vol.60,No.3(Sep.1922), P.182

9 Hussien Ahmed, Islam in the Nineteenth Century Wallo, Ethiopia Revival, Reformation and Reaction ( Netherlands:Koniklisk Brill,2001) p.34

10 Hussein Ahmed, "the Historiography of Islam in Ethiopia," Journal of Islamic Studies,Vol.3, No.1 (January, 1992), p.16

11 Jorome Lobo, A Voyage to Abyssinia (London : 1887), p.25

12 Ibid.

13 S. Perrera, Abyssinia, Translated from the German of Dr.(Henery)W.Thiersch.(London:James Nisbet\&co.,21: Berners Street n.d), pp.50-51
According to Beckingham the very many sources of Europeans about Ethiopia are mainly written by priests who have their own particular interest in the religious dogmas and practices of the Ethiopian Church. As a result they may not be in a position to be enthusiastic in stating the various aspects of the country and hence it is unavoidable task to be free from biases. This is especially evidenced in their approach towards Muslims ${ }^{14}$. As clearly indicated by Matteo Salvadore "as the history of pre modern European encounter will make clear, a key contingency in the development of the relation between Africa and Europe was the latter's phobic relation with Islam and the identification of Muslims as the ultimate others." 15 This is also true to the many European travelers and missionaries who came to Ethiopia at different periods. The Early seventeenth century Portuguese missionaries Pedro Paez, Jerome Lobo and Farnsico Alvareth, James Bruce of Scotland who published an indispensable work on the Blue Nile, Cornwallis Harris , a British Citizen who have produced a very important account on the highlands of Ethiopia and the two German missionaries of Isenberg and Krampf of the nineteenth century, all preferred to indiscriminately identify Ethiopian Muslims as "Mohammedans, Moors , Family of the false Prophet or Fanatic Mohammedans."They did not have any reasonable justification to quote, but many of these travelers and missionaries and their own compatriots failed to consider Ethiopian Muslims role for the great cultural and religious diversity of Ethiopian and most often preoccupied with associating them as outsiders and ultimate others.

A preposterous description of Ethiopian Muslims was made by Jerome Lobo who came to Ethiopia in the early seventeenth century said that "in all my dealings with the moors, I have always discovered in them an ill-nurtured cowardice, which makes them insupportably insolent if you show them the least respect and easily reduced to reasonable terms when you treat them with high hand." ${ }^{16}$ Such a tradition is also appeared in the local Christian writers popularly known as chroniclers who have developed their own concept of Islam and portrayed Muslim communities and their leaders as something different. Suffice to mention is the Chronicle of Amade Tsiyon. Haggai Erlich for instance had shown how the sultan of Ifat -Sabr al-Din, was described. According to the Chronicle the leader was considered as, "this rebel son of viper, seed of snake, son of a barbarian, from the origin of Satan and enemy of the righteousness who opposed the religion of Christ" 17 As to the same chronicles description all the Muslims of Ethiopia were "liars, and Hyenas and dogs, son of viper and seeds of evil ones." 18 Such apparent prejudiced attitude towards Islam and the Muslims of Ethiopia were not the only manifestations of these local Chroniclers. How could it be logical to compare a human being with a hyena or a snake? Such an exaggeration and rampant description was also incorporated in Ethiopian Christian tradition about Imam Ahmed Ibn -Ibrahim al-

14 Charles Beckingham, "European sources for Ethiopian History Before 1634,"In: Paideuma,Bd.33 European sources for Sub-Saharan Africa before 1900: use and Abuse(19870), p.173

15 Lobo, p. 25

16 Erlich. p.

18 Ibid. 
Gazi(nicked name Ahmed Gragn). In fact what has been unnoticed by many historians of the past periods and even the most contemporary ones is that such an approach followed in these literary works are written by priests or monks whose ideas are most importantly leaning to the kind of beliefs they follow. ${ }^{19}$

Christian Ethiopia had preserved a good history of peaceful relation and collaboration with Islam both on International and local issues which continued until the end of the thirteenth century. Ethiopian Muslims had long been active participants in the local economy and had played an immense contribution to the regional economy of the Red Sea. ${ }^{20}$ Historically, Ethiopian Muslims has been living throughout the empire intermix with the Christians. They belong to different ethnic groups, speaking a variety of Semitic, Cushitic and Nilo-Saharan languages. They have been also engaged in practicing various means of production. As clearly indicated by Erlich "Muslims claimed no ethnic differentiation and used Ethiopian language and hence they contributed to the diversity of Ethiopian culture, rather than polarizing it." ${ }^{21}$

Rey tried to describe the religious activities of Christian Abyssinians and other religious followers in the country. According to his observation, Abyssinians did not allow other religious groups to freely proselytize their faith and they (Abyssinians themselves) do not made any effort to do so due to lack of education and the sheer ignorance of the priesthood who are great in numbers. ${ }^{22}$ As to the former claim it might be true, but the latter presumption may lack vigorous analysis and is considered as an attempt of overlooking the great achievements of the great "holy" men like St. Tekle Haimanot. It is still evident in most parts of the country that Churches and monasteries are sprinkled everywhere, a clear indication that the religion had been deep-rooted in the empire. The great historical works of holy men and the immense attachment of the religion to the various administrative levels of the country might have contributed to the spread of the religion. Saint Tekle Haimanot, to mention few among the very prominent personalities was known to establish monasteries in nonChristian areas and waged heroic struggles against indigenous nature religions, and attracted people to Christianity by their power, their holiness, their miracles and services which they could perform in the new Christian order. ${ }^{23}$

A similar observation engraved with personal biases is also made by Waldameir, a British missionary in the court of emperor Tewodros that the Muslims of Wollo whom he called Mohammedans, did not know the principle of the Quran and simply accepted the religion of Islam for fear of persecution by the forces of Ahmed Gragn during their conquest of Wollo. ${ }^{24}$ This is a clear remark reflecting the personal disorder 19 M. Abir, p.73

20 Matteo Salvadore, “The Ethiopian Age of Exploration: Prester John's Discovery of Europe;1306-1458," Journal of World History,vol.21,No.4(December 20100, p.600

21 Erlich, p27.

22 Rey, p. 182

23 Jhon Illife, Africans:the History of the Continent $2^{\text {nd }}$ edition(Cambridge:Cambridge University

Press,2007),p.60

24 Waldamier Theophilus, Ten Years with king Theodore in Abyssinia and Sixteen years in Syria(London: the Oraphens Printing press,1886), p. 33 which had happened to him during his stay in the province of Wollo. The contribution of the ulammas and the traders and the conquest of Ahmed Gragn (though there was no forceful conversion as compared to other regions) seemed to have been overlooked by this missionary for the spread of the region of Islam in the region. The struggle between emperor Tewodros and the great Muslim rulers (of the Mammedoch Dynasty) of the time, where the former had made a fierce onslaught against the latter could be an indication that the religion had entrenched in the region under consideration.

Withstanding the very many differences between Islam and Christianity in their respective religious dogmas, Waldamier argued that the only main difference between the followers is their greeting of each other when they meet. The Christian saying good morning and the Muslim answers Alhamdulillah (God be praised) in Arabic language is considered as the only difference between the two. ${ }^{25}$ Perrier's observation that a Christian wearing of a blue silk cord, popularly known as mateb, around the neck to distinguish him as a Christian from his fellow Jew or Muslim² ${ }^{26}$, and the differences in their meal that a Christian may not eat a meat which is slaughtered by a Muslim and the vice-versa was not even understood by Waldameir.

Another ignorant observation and description towards the Oromos of Wollo, who were converted to Islam following the eventful conquest of Ahmed Gragn was made by the German Missionaries of Isenberg and Krampf. The region Wollo was historically used as a place of contact and interaction of Semitic north, northwest, and the Cushitic southern and southeastern plains. ${ }^{27}$

The part of Wollo, particularly the Borkena valley "have been a blood stained zone over which the fierce racial and religious struggles have won over since the days of Amde Tsiyon and king of Haq ed-Din , the sultan of Ifat." ${ }^{28}$ It was also through this valley that the Muslim conquest of Ahmed Gragn took place. ${ }^{29}$ The Wollo region has "been a scene of many encounters between races and religions and therefore exhibits a considerable ethical heterogeneity. ${ }^{30}$

The missionaries' description of the Wollo Oromo as "very bigoted Mohammedans where the religion of Islam had contributed to add a great deal to the depravity of them" 31 is a clear reflection of their religious biases against these peoples' religion. The missionaries further added that "they themselves [the Wollo Oromos] confess that they are to be compared with a hyena. ${ }^{32}$ Such a description is out of human image and is rampant, where no religions in the world contribute

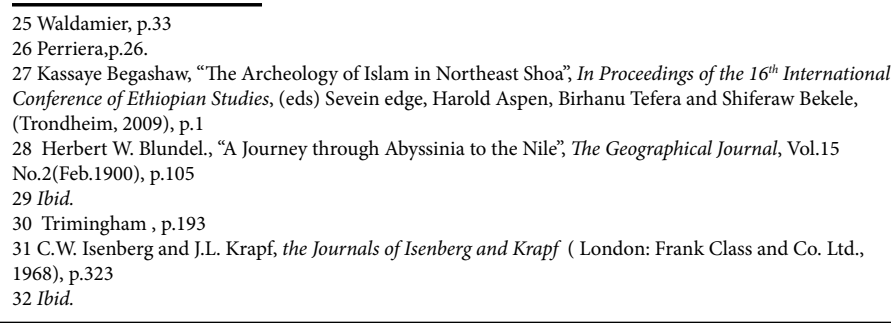

26 Perriera 26.

27 Kassaye Begashaw, "The Archeology of Islam in Northeast Sho", In Proceedings of the $16^{\text {th }}$ International Conference of Ethiopian Studies, (eds) Sevein edge, Harold Aspen, Birhanu Tefera and Shiferaw Bekele, (T)

No.2(Feb.1900), p.105

31 C.W. Isenberg and JL. Krapf, the Journals of Isenberg and Krapf ( London: Frank Class and Co. Ltd. 32 Ibid. 
to the depravity of human characters. Their own distorted concept of Islam and the Muslims of this region might have predictably contributed to develop and maintain such kind of attitude. Haggai Erich's discussion of Islam "as it offered so appealingly to other peoples-combining monotheism with comprehensive harmonious set of legal answers to problems of earthly existence" 33 is a well stated scholarly outlook towards Islam.

A very still practiced religious and cultural contingency of the Wollo Oromo known as Wadaja ceremony was also commented by the same German missionaries but with a degrading and latent understanding. It is a common tradition to conduct a communal praying (other than the five times praying within a day) ${ }^{34}$ among the Muslim Oromo communities of Wollo. The tradition had been playing an important role in the social life of these communities. Originally as an Oromo cultural practice, it was said to have expanded throughout the region in the seventeenth and eighteenth centuries and had acquired some Islamic elements within it. ${ }^{35}$

The claim made by Rey that Abyssinians do not make efforts to convert their subjects to their own national religion, Christianity $^{36}$ is not convincing. Suffice to mention is the reign of emperor Tewodros II (1855-1868) and emperor Yohannis IV (1872-1889) who were forcing the poor Wollo Oromo to accept Christianity. During his stay in the court of Tewodros, Waldamier had observed the kings' forceful conversion of the peoples of Wollo into Christianity. ${ }^{37}$

Many Muslims including pagans were forced to accept Christianity without any prior order. His successors Menelik and Yohannes had also followed the same tradition in converting their subjects into Christianity. During their travels to Wollo, king Menelik and Yohannes had devastated many villages, plundering properties and killing many peoples who opposed the forceful conversion. Waldameier had even portrayed emperor Yohannes as the most malicious of the time especially against the Muslims of Wollo. He described the atrocities up on the Muslims of Wollo as "plundering villages with his large army, destroying the homes of the poor peasants and butchering men and women for trifling causes. He is a conqueror and wild warrior, but not able to rule with justice, nor to improve the condition of his country and people." 38

Associating despised activities to Ethiopian Muslims and Jews is one of the manifestations of Europeans who came to Ethiopia at different times. The Muslim traders, jeberties who prominently spread the religion preferred to settle in urban areas. They tend to frequently made travels to the coast and

\section{Erlich, p.15.}

34 Isenberg and Krapf, p. 323

35 For further explanation about Wadaja see, Assefa Balcha, "Wadaja Ritual:Portrait of a Wollo Cultura Coping Mechanism," Eastern African Literary and Cultural Studies,3.1. pp:40-52

36 Rey, p. 182

37 Waldamier,P.137

$38 \mathrm{Ibid}$.

39 Erlich, p. 41 the interior regions. ${ }^{39}$ James Bruce had made reference that the huge mass of the trading activities in the country was carried out by Muslims whom he called as Mohammedans. He also further added that they (the Muslims) are the sole masters of the trade who went to the Sea coast, as it was impossible for the Christians of Abyssinia to go to the sea. ${ }^{40}$ Their occupation however was most significantly considered as despised by Christians and the dominant inhabitants where they were looked down by their own communities. ${ }^{41}$

The Muslims and the Jew inhabitants of Abyssinia were known for their huge intelligence in their mechanical authenticity and their superior habits of industry. As to Hennery James, all the weavers are Muslims and all the builders and artisans are Jews. Associating characters such as insincerity and deceitfulness and in hospitability is most commonly given for these societies by the dominant inhabitants. ${ }^{42}$

Though pride is not their only blunder, they however supported the local economy through various means. The Muslim traders for instance carry different products to the coast and return back with various items to the interior regions of the empire. Mr. Bruce had described Muslim traders of Gondar as active caravans who go far to the south by crossing several districts of the Oromo country by carrying breads and large needles, myrrh, coarse cloths made in Begemdir and pieces of blue cotton clothes. They may stay long periods, up to one year and in return come with slaves, civet, wax, hides and cardamom and also a great quantity of ginger collected from farther in the south, from Enaryea. ${ }^{43}$

According to the same travels reference to the Muslim inhabitants of about a thousand houses in Gondar, they were engaged in delivering a great service in protection of the king and his nobility's properties. They were active and laborious people in preparing equipage materials for expedition; like loading mules and baggage but they were never forced to fight on the other side. Apart from trade activities, some Muslims may also engaged in agricultural activities, but was insignificant because they were not allowed to own land as compared to other inhabitants. ${ }^{44}$

The Other major issue which is frequently mentioned by Europeans was concerning Ethiopian Muslims sole engagement in slavery and slave trade. According to Harris the different local civil wars which had been fought in the past had created favorable conditions for the Muslim slave dealers in the country. But the claim he made that the Muslim traders in this human cargo was fueled by their "religious motive" is unsubstantiated argument, a clear reflection of his personal predicament. He boldly remarks that the act was solely

40 Bruce,p. 39

41 Hussien Ahmed, "the Historiography of Islam..," p.20.

42 Henery James, Routes in Abyssinia (London:St. Martin's Lane,1867),p. 16

43 James Bruce, Travels to Discover the source of the Nile in the Years 1768,1769,1770,1771,1772, and

1773,5 vols (Edinburg, 1790), p. 261

44 Ibid. 
relegated to Muslims which he impudently referred to them as "bigoted disciples of the Prophet." ${ }^{45}$ In fact the commerce in slaves was most significantly conducted by the Arabs or Muslim Ethiopians due to the fact that they were not bound by the Fetha Nagast, which outlawed Christians not to partake in trading in slaves. ${ }^{46}$ Major Harris has provided reasons for Ethiopian Christians non engagement in trading in slaves for partly fear of their enemies (Muslims in the Red Sea area) and partly because they consider it as a sole occupation of Muslims. ${ }^{47}$ According to perriera, the Christians of Abyssinia were not involved in the slave trade due to the fact that they recognized it as sinful, though they bought slaves, they do not sell them and treat them with great care in their houses. ${ }^{48}$

But there are some indications that trade in slaves were also conducted by Christian commoners in Abyssinia. Richard Pankhurst said that "a Christian could in any case always circumvent the law [Fetha Nagast] by operating under the cover of a Muslim agent." ${ }^{49}$ Teshale Tibebu has also argued that the Abyssinian Christians also had engaged in this commercial venture. He said that "Christians were linked to slavery only as buyers, not as sellers did not square." ${ }^{50} \mathrm{He}$ mentioned that during Meneliks territorial expansion of Menelik in the south, a large number of war prisoners were brought and were changed to slaves.

\section{Ethiopia in the midst of "a Muslim stormy area"}

It has been customarily apparent in both the European and Ethiopian Christian traditions that Ethiopia has been described as "a Christian island set in the midst of a stormy Muslim area. ${ }^{51}$. As Trimingham has indicated:

....the Region is entirely surrounded by Muslims, for Islam is the religion of the Northern Sudan, Egypt, Arabia, and the coastal regions of Kenya; only in the south and the south west does it border on the pagan countries in the southern Sudan and the north-west frontier province of Kenya. Owning to the proximity of Arabia Islamic influence has been felt since the days of the Prophet Muhammed, with the result that today half of the people of the region are Muslims. ${ }^{52}$

Many local as well as foreign writers argued that such Ethiopia's location encircled by the Muslims has been remained a threat for the survival of its independence Following the rapid spread of Islam and occupation of the Red sea by the Muslim Arabs, the situation seemed to have created a sense of fear and uncertainty for the future independence of Ethiopia. The beginning of Islamic influence in the seventh century and its gradual expansion to the Middle East, the Red Sea coastal areas and the Nile Valley regions had effectively resulted in the isolation of Ethiopia from the Mediterranean Christian world

45 Harris, W. Cornwallis, The Highlands of Aethiopia, 3 vols (London: A.Spottis Woode, 1844),p.312 46 Rechard Panchurst, Economic History of Ethiopia, 1800-1935 (Addis Ababa: Haileselassie I University press, 1968), p. 60

47 Harris, p. 132

48 S.Pierrera, p.43

49 Pankhurst,p. 88

50 Teshale, p. 57

51 Hussien Ahmed, "The Historiography of Islam in Ethiopia",p.18, ; Gerald H. Portal,C.B, My Mission to Abyssinia (London: Bedford Street, Strand,w.C. ,1892),P. iv

52 Trimnham, p. 30 which continued until the period of modern imperialism..$^{53}$ The Red Sea had been serving for many centuries as a principal channel of international trade which connected traders from the Far East, Europe and the Middle East. ${ }^{54}$ Islam crossed the Red Sea area mainly through traders and holy men rather than with military force. Its gradual penetration through its agents into the highland regions of Ethiopia had eventually enabled it to be a competent force with Christianity for supremacy over the cultural and political spheres in Ethiopia and the neighboring regions. ${ }^{55}$ The appearance of Muslim powers around the Red Sea area had its own economic repercussion for Ethiopia as it lost the control of the region which was the principal artery of its external commercial ventures. ${ }^{56}$

Following the emergence of Islam and the growth of the Red Sea trade, a huge number of ulamma(holy men)began to migrate from Arabia and played a prominent role for the expansion of the religion to North Africa, Egypt, and to Europe. ${ }^{57} \mathrm{Up}$ until the Ottoman occupation of the sixteenth century, Islam spread into Ethiopia peacefully where was no any military threat was made against the country.

Withstanding the very peaceful nature of Islamic expansion to the Ethiopian region, Perriera boldly argued that "Ethiopia had been presenting a humiliating and galling object to the more fanatical followers of the prophet." ${ }^{\circ 8}$ This claim is in fact beyond exaggeration and no jihad had been waged against the mountain citadel of Ethiopia. Perrier's assertion that the "the whole people of Christian Abyssinia were called to resist the fierce onslaught of the Muslim Arabs"59 does not clearly show the exact period and condition of the invasion made against Ethiopia. H.Portal in his account My Mission to Abyssinia has also made a similar contention that "every generation had incessantly made a fierce onslaught against the bigoted Muslim crowds." According to Hennery Stern, "the people of Abyssinia who are nursed in war and expert in the use of lance the whole country united their forces to defend their religion and their home against the invading foe "and as a result this Christian state was not overwhelmed by the resistless floods of Islamism." 61 According to these authors, it was because of this reasons that Abyssinians had kept their religion intact and its Christian religion when all the nations were surrender to the sword or to the influence of Islam. It was therefore became a fashion of the day in these literary works to observe the Muslim Arabs of the Red Sea who begirt the empire as an incessant threat for the independence of Ethiopia.

On the contrary many of the literatures on Islam in Ethiopia revealed that no jihad had been waged against Ethiopia. Sergew has clearly indicated that the Muslim Arabs in the

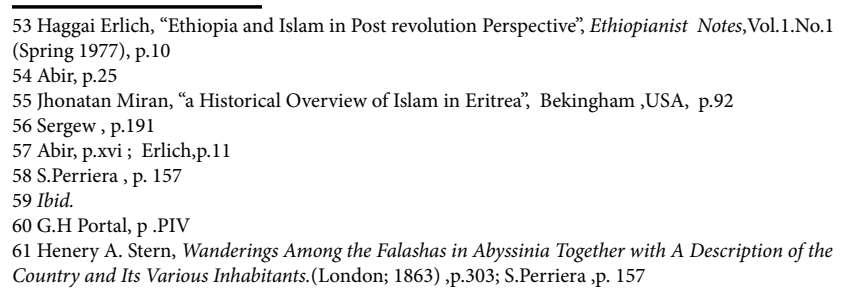


surrounding areas of the empire "did not actually threaten the country by direct and immediate wars" but they thwarted the country's relation with the outside world. ${ }^{62}$ Trimingham has also remarked that by the time when the Arabs had made their steady expansion and controlled many countries, they did not however threaten Ethiopia through jihad. ${ }^{63}$ Even during the height of their power where they could unite their naval and ground forces for effective control of many areas, they desisted from directly opening jihad against Ethiopia. ${ }^{64}$ The other most astonishing thing which became a matter of debate among scholars on Islam in Ethiopia is the country's highland fastness which had prevented the country from the Muslim Arab invasion. Trimingham for instance said that Ethiopia's highland citadel have been a stun against the Islamic invasion from the Arabian Peninsula and the eastern coast and from the Nile Valley area. ${ }^{65}$ According to him, the strength of Christian Ethiopia might have also arisen from this strategic importance. On the other hand Abir has presented a different view and asserted that "the strength of Christian Ethiopia, strategically south of Egypt and near the Indian Ocean was exaggerated." 66

In spite of the polarized views presented above, what has been unnoticed by many writers, both foreign and local, was their trifling emphasis on the cultural image of Ethiopians by the Muslim Arabs. Prophet Mohammed's order to his sahabas "Leave the Abyssinians as long as they do not take offensive" ${ }^{67}$ might have been overlooked. Sergew for instance was skeptical of the practical implementation of the prophet's order on Ethiopia and strongly argued that the isolation of Ethiopia from the outside world because of the Muslim Arabs control of the Red Sea was "as harmful as jihad." 68 This seemed an arbitrary judgment, since hundreds of years people had come and settled and settled in the Red Sea coast line from the Arabian Peninsula. He further added that the expansion of the religion from this coast to the highlands of Ethiopia might have led to the decline in the development of cultures in Ethiopia $^{69}$ rather than its contribution to the medley of cultures and religions to the region under consideration. Salvador's scholarly explanation might have probably avoided such state of confusion in that "Ethiopians do not have a history of their own making but rather experience historical change as a result of exposure to the Euro-Christian engine of history." $" 70$ He strongly came up with the idea that "whenever isolation prevails, history supposedly stops." 71

The Sahaba episode, which was taken as a decisive period in the contact of Islam within the court of Axum had eventually contributed its own role for the gradual and peaceful spread of Islam and Islamic culture in Ethiopia. Therefore, the claim made by Hennery Sern that "the sword of Islam sought to

62 Sergew Hableselassie, Ancient Ethiopian History, p.191

63 Trimingham, p.46

64 Erlich, p. 9

65 Trimingham,p.xv

65 Trimingha

67 Trimingham, p.60 ; Erlich,p.10 Sergew Hableselassie, p.191

68 Sergew , p.191

69 Ibid.

70 Matteo Salvadore, "Muslim Partners, Catholic Foes: the selective Isolation of Gondarine Ethiopia, North East African Studies", Vol.1, No.19(2012) p.52

$71 \mathrm{Ibid}$. sweep across from the mountain regions of Ethiopia' ${ }^{72}$ into the interior regions is unsubstantiated argument. In fact expansion of Muslim military power has speeded up the process of the dissemination of the religion in many parts of the world and this is also true in certain periods of Ethiopian history, but it has to be understood that it is not a primary condition for the expansion of Islam. ${ }^{73}$

From the moment of its initial contact of Islam in Ethiopia, it is considered as a historical, social and cultural constituent of Ethiopia. It is also a clear remark of reflecting Ethiopia's long history of social amalgam which in turn contributed for the development of the diverse culture of its society.

\section{CONCLUSION}

Many of the commentaries on Islam in Ethiopia, especially the European travelers, missionaries, local writers as well as some professionals in the field considered Ethiopia as a Christian island surrounded by a heathen sea. The European travelers who came to Ethiopia at different periods have had a phobic attitude towards Ethiopian Muslims as well as with the Islamic communities of the surrounding region of Ethiopia, and tried to associate them as an incessant threat against the Empire of Ethiopia. Many of them failed to give a due recognition to the peaceful nature of the expansion of the religion to the Ethiopian region and boldly argued that Islam spread by the sword. Muslims at the height of their power in fact were able to control many parts of the world through military force which they were not able to apply it in Ethiopia, "a land of righteousness", which is embodied in the Prophet's hadith "Leave the Abyssinians as long as they do not take offensive." Its gradual penetration through its agents into the highland regions of Ethiopia had eventually enabled it to be a competent force with Christianity for hegemony over the cultural and political spheres in Ethiopia and the neighboring regions. But many of the European travelers and missionaries argued that much generation of Ethiopians had been stood as a stun against the forceful expansion of Islam to the Ethiopian region and as a result Christian Abyssinia had for centuries kept their religion intact. This is however beyond exaggeration and Ethiopia is a country of medley of religions, cultures and various linguistic groups.

Historically, Ethiopian Muslims has been living throughout the empire intermix with the Christians. They belong to different ethnic groups, speaking a variety of Semitic, Cushitic and Nilo-Saharan languages. Though, Christianity was as a national religion and the Semitic speaking inhabitants who have been inhabiting stretching from the north to the central highlands predominates, Abyssinia had traditionally been diverse society consisting of non-Semitic pagan and Muslim elements of equal historical status. Therefore in much of the literatures especially of the Europeans missionaries and travelers, there is a misnomer description of Ethiopian Muslims.

72 Henery p.303.

73 Husien Ahmed, Islam in the Nineteenth Century Wallo...., p.32 


\section{REFERENCES}

1. Abir, Mordechai. Ethiopia and the Red Sea: the Rise and Decline of the Solomonic Dynasty and the Musslim European Rivalry in the Region .New York:Frank Class Company Limited, n.d.

2. A. Stern, Henery. Wanderings among the Falashas in Abyssinia Together with a Description of the Country and Its Various Inhabitants.London; 1863.

3. Assefa Balcha, "Wadaja Ritual:Portrait of a Wollo Cultural Coping Mechanism." Eastern African Literary and Cultural Studies, 3.1. pp: 40-52

4. Beckingham ,Charles. European Sources for Ethiopian History before 1634. In: Paideuma, Bd.33 European Sources for Sub-Saharan Africa before 1900: Use and Abuse 19870.

5. Bruce, James. Travels to Discover the source of the Nile in the years 1768,1769,1770,1771,1772, and 1773 . 5 vols. Edinburg, 1790.

6. Deresse Ayenachew. "Environmental Descriptions of European in Ethiopia(16th c to 19th c)" :In Climatic and Environmental Challenges: Learning from the Horn of Africa. Addis Ababa:Center Fracaisdes etudes ethiopiennes, 2016

7. Erlich , Haggai. Ethiopia and the Middle East. London: Lynne Reiner Publishers, 1994.

8. "Ethiopia and Islam in Post revolution Perspective", Ethiopianist

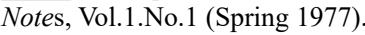

9. Harris, W. Cornwallis. The Highlands of Ethiopia, 3 vols .London: A. Spottis Woode, 1844.

10. Hussien Ahmed. Islam in the Nineteenth Century Wallo,Ethiopia Revival,Reformation and Reaction .Netherlands:Koniklisk Brill: 2001.

11. "The Historiography of Islam in Ethiopia." Journal of Islamic Studies. Vol.3, No.1 (January, 1992), .15-46.

12. Illife, Jhon. Africans: the History of the Continent, 2nd edition .Cambridge:Cambridge University Press,2007.

13. Isenberg, C.W. and J.L. Krapf, The Journals of the Rev. Messrs. Isenberg and Krapf, Missionaries of the Church Missionary Society, detailing their proceedings in the Kingdom of Shoa, and Journeys in Other Parts of Abyssinia, in the Years 1839, 1840, 1841, and 1842, 1843.

14. James, Henery. Routes in Abyssinia. London: St. Martin's Lane, 1867.

15. Kassaye Begashaw. "The Archeology of Islam in Northeast Shoa", In Proceedings of the 16th International Conference of Ethiopian Studies, (eds) Sevein edge, Harold Aspen, Birhanu Tefera and Shiferaw Bekele, Trondheim, 2009

16. Lobo, Jerome. A Voyage to Abyssinia. London ,Paris,New York \&Melborne: 1887.

17. Miran, Jhonatan. “a Historical Overview of Islam in Eritrea.” Bekingham ,USA n.d.

18. Panchurst, Rechard. Economic History of Ethiopia, 1800-1935. Addis Ababa: Haileselassie I University press, 1968

19. Portal, Gerald H. My Mission to Abyssinia. London: Strand,w.C. ,1892.

20. REY , C.F. "Abyssinia and the Abysinians of Today". The Geographical Journal. Vol.60, No.3 (Sep.1922).

21. Russel ,Michael. The History of Nubia and Abyssinia. New York: J\&.J.Harper, 1883 .

22. Salvadore, Matteo. "The Ethiopian Age of Exploration: Prester John's Discovery of Europe; 1306-1458.”.Journal of World History. vol.21, No.4 (December 2010).

23. Muslim Partners, Catholic Foes: the selective Isolation of Gondarine Ethiopia, North East African Studies, Vol.1, No.1 .

24. Sarah M.S. Pereira. Abyssinia. London: James Nisbet \&Co., 21 Berners Street.

25. Sergew Hable Selassie. Ancient and Medieval Ethiopian History to1270. Addis Ababa:United Printers, 1965.

26. Teshale Tibebu. The Making of Modern Ethiopia, 1898-1974. Lawrenceville: The Red Sea press, 1995.

27. Theophilus, Waldamier. Ten Years with King Theodore in Abyssinia and Sixteen Years in Syria. London: the Orphans Printing press, 1886.

28. Triminghan, J. Spencer. Islam in Ethiopia. London: F. Cass, 1952.

29. Weld Blundel, Herbert. A Jouney through Abyssinia to the Nile. The Geographical Journal, Vol.15, No.2 (Feb.1900), pp.97-118 